\title{
The structure and the leadership: The actualization of good management of Indonesian University
}

\author{
Risanty*; Sambas Ade Kesuma \\ Accounting Departement, Universitas Sumatera Utara, Indonesia \\ *To whom correspondence should be addressed.Email: risanty.usu@ gmail.com
}

\begin{abstract}
The objective of this paper is to discuss the concept of good university governance and the structure of university in Indonesia. In particular, the paper focuses on the structure of university in order to improve the good university governance in Indonesia. Good University Governance is basically setting the organizational structure, the process of business, as well as program and activities in the planning procedure. Leaders are different from managers. The leader is chosen and earned the academic leadership and the authority. Academic leaders are mandated to lead and a combination of academic leaders and managers. A university should apply academic leadership in every level. It is necessary to implement the checks and balances of executive authority, which can be performed by the university and faculty academic senate. Avoid conflicts of interest as well as multiple positions in implementing good governance in a university.
\end{abstract}

Keyword: Good university governance, University structure, University leadership

JEL Classification: M1, L3

\section{INTRODUCTION}

Education is an important part in a country and became one of the main indicators to measure the progress of a country. Through the education as well, a country strives to improve the competitiveness of human resources that can provide a positive impact for the country. As an educational institution, the university became a major institution to generate human resources quality.

However, over the times, in order to face the economic transformation, technological and social conditions, the university is required to balance its role. Not only for knowledge transfer, but it may become an intellectual center while stays relevant to the environment, technology and social conditions (Stevenson, 2004). The objective of a universities is expected not only to create qualified human resources and ready to work, but more than that, becoming the nation's agents in manage and directing the changes in the nation (Sadjad, 2004; Stevenson, 2004).

Organization of universities have an extensive coverage that includes the management of science, lecturers, human resources support, students, facilities and infrastructure of academic, academic programs, academic information on the three fundamental tasks of university (education, teaching and public services) (Sadjad, 2004).

Universities in Indonesia is an educational institution that aims to prepare qualified human resources who have the academic ability and professional capability in order to 
improve and ensuring the national life (Muhi, 2010). Generally, the university in Indonesia may consist of colleges, institutes, and polytechnics. Universities can organize academic, professional and vocational education programs diploma (D1, D2, D3, D4), undergraduate (S1), master (S2), doctorate (S3), and specialists. According to UndangUndang No. 12 Tahun 2012 pasal 1 ayat 1 on higher education, the university is an institution of higher education with the level of education after secondary education which includes diploma, undergraduate, master program, doctoral and professional programs, as well as specialist program.

Good governance is one of the important aspect on the management of university these days. Good governance is a system that will guide and controls the university organization. With the implementation of good governance, the university is expected to improve its image to the public, that eventually will increase the public trust and participation on the role of universities (Muhi, 2011; Sumarni, 2010). Hence, every university should start and establish good governance with the principles of transparency, independence, accountability, and responsivness. The fourth perspective can be a good indicator in order to implement good governance at university in Indonesia (Jalal \& Supariadi, 2001).

The implementation of good governance on university in Indonesia cannot be separated from issues of accountability and program planning activities, as well as indicators of performance assessment. The Government of the Republic Indonesia requires the implementation of good governance in all public and private universities in Indonesia (Sumarni, 2010). However, the implementation of good governance is faced several challenges in particular areas, especially the issue of transparency and accountability to implement certain activities. Based on the audit report of the Supreme Audit Agency (Badan Pemeriksa Keuangan) in 2013 noted that several issues regarding transparency, accountability and responsibility, as well as the irregularities in several public universities in Indonesia (Badan Pemeriksa Keuangan Republik Indonesia, 2013).

The purpose of this paper is to discuss the concept of good university governance and the structure of university in indonesia. In particular, the paper focuses on the structure of university in order to elevate the good university governance in Indonesia. Moreover, this paper consists of four section as follows. Section one present the introduction of the university, good university governance and several issue in the implementation of good university governance in Indonesia. Section two provide a brief discussion related to the university in Indonesia and the structure of university in Indonesia. Section three discusses the leadership in higher education. Section four provide discussion related to the actualization of good management in the university. Finally, section five present a summary and recommendation.

\section{STRUCTURE OF PUBLIC UNIVERSITY IN INDONESIA}

Higher education throughout the world has undergone intensive changes during these decades, including in Indonesia. In general, most of the Western countries attempt to deal with the changes by implementing a large-scale structural reformation program, which aims to change the pattern of regulation and structure of higher education (Davidovitch \& Iram, 2015; Norton, 2014). Meanwhile, in European countries, various higher education reformation programs have been carried out since the early 1980s, the objective is to restructure the relationship between the government, society, and institutions of higher education (Dobbins \& Knill, 2009). In addition, in Australia, a 
committee was formed with the purpose of evaluating and examine the governance structures and the changing needs for the management of higher education institutions in the context of the new global economy (Bradley, Noonan, Nugent, \& Scales, 2008).

Currently, various countries such as France, Sweden, Turkey, and Russia tend to use higher education structure patterns towards a country-centered structural approach (Mizikaci, 2006; Panova, 2008). This structural approach views a higher institution as a public institution operated by the government with the aim of meeting national objectives (Davidovitch \& Iram, 2015). Moreover, the government directly operates and coordinates entire aspects of higher education programs, including admission requirements, determining candidates, and admission of academic faculties, examinations, curriculum, and other academic programs (Davidovitch \& Iram, 2015; Dobbins, Knill \& Vögtle, 2011). The university is strictly monitored, the administration is controlled by the government, and the university is given sufficient autonomy (Dobbins, Knill \& Vögtle, 2011).

Meanwhile, in Australia, a university is viewed as a large industry and capable of generating high profits. In this country, higher education structure patterns are generally based on market-oriented structure approaches or also known as entrepreneurial universities (Bradley et al., 2008; Davidovitch \& Iram, 2015). According to this structural approach, the government does not take steps or decisions related to the design and planning of the higher education system (Bradley et al., 2008). Instead, the government promotes the competition and increases the quality assurance as well as transparency in academic institutions level (Davidovitch \& Iram, 2015; Lokuwaduge \& Armstrong, 2015).

In the context of Indonesia, according to the law of the Republic of Indonesia number 12 of 2012 article 4 which regulates the function of higher education, the function of universities in Indonesia are: 1) Develop the character, capacity, and civilization of the nation's dignity in the context of the intellectual life of the nation; 2) Developing innovative, responsive, creative, highly-skilled, competitive, and cooperative academic community through the implementation of Tridharma; 3) Developing science and technology by observing and apply the value of humanities.

In addition, the law of the Republic of Indonesia number 12 of 2012 article 5 which regulates the objective of higher education have mentioned four main objectives of universities in Indonesia, namely: 1) Developing the potential and talents of students in order to become a qualified human resource for the interests of the nation; 2) Generates the best graduates who master science and technology to meet the national interests and increase the nation's competitiveness; 3) Generates science and technology through the research and apply the value of humanities for the benefit of the national progress; 4) The realization of community service based on reasoning and research works that are beneficial in promoting the general welfare and educating the nation.

In order to understand the good university governance in Indonesia, there are several important points that need to be explored (Tamin, 2015), namely: 1) The higher education system and the position of the university; 2) The dignity of the university; 3 ) The governance and the university accountability framework; 4) The organization and governance; 5) Leadership and election of university leaders

Currently, the management and regulation of universities in Indonesia conducted by the Ministry of Research, Technology and Higher Education. Moreover, based on the laws and regulations, every university in Indonesia must have a Board of Legal Education, 
which serves delivering fair and quality to the students, non-profit, and independent in order to promote national education (Muhi, 2011; Sumarni, 2010; Tamin, 2015).

According to the Indonesian Government Regulation No. 60 of 1999 on higher education, the public university is part of the government bureaucracy in education, the organizational structure of public universities in Indonesia consist of the Board of Trustee (Majelis Wali Amanat), the audit board (Dewan Audit), the university academic senate (Senat Akademik Universitas), The rectorate (Pimpinan Universitas), the dean of faculty (Dekan Fakultas), the directorate of planning and development (Badan Perencanaan dan Pengembangan), and the internal audit unit (Unit Audit Internal) (figure 1). In the organizational structure, the functions and role of these new bodies such as the Board of Trustee, the audit board, the university academic senate and the internal audit unit is very essential because it is the key of good governance implementation on public university in Indonesia.

The structure has adopted a the structure of government with the executive and legislative bodies that reflect elements of democracy and the mechanism of checks and balances in the decision making process, as well as the application of accountability principle.

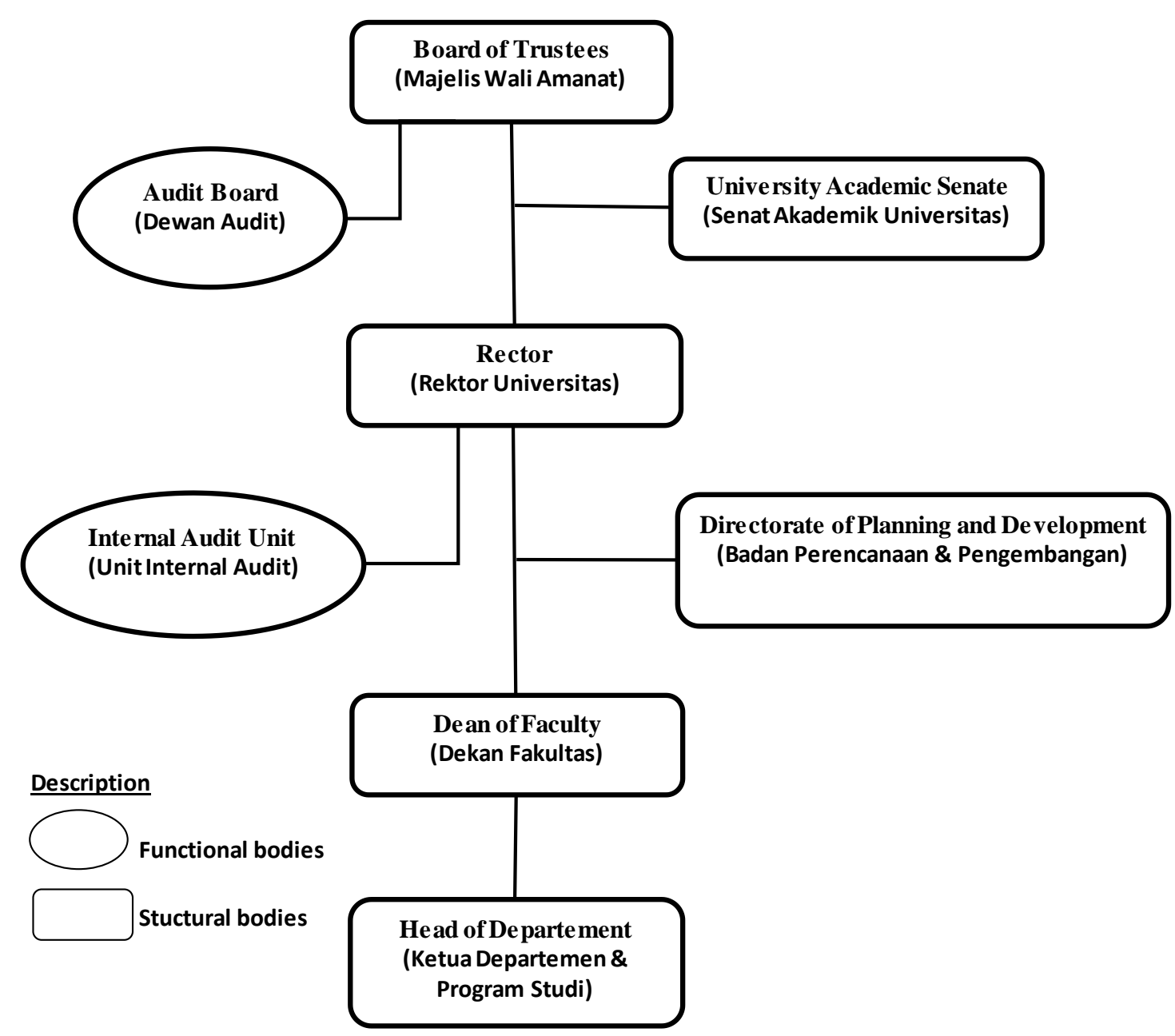

Figure 1. Organizational Structure of Public University in Indonesia Source: Indonesian Government Regulation No. 60 of 1999 
The organizational structure of public university above provide several important part on the management of university. The board of trustee is the highest governing body of the university, which is a forum of deliberation that represents the interests of the various parties (public, government, and academic society). The board of trustee is also an entity that also represents the principles of transparency, public accountability and professionalism in the management of the university. In general, the principal task of the board of trustee is to provide guidance to the management of the university, in the form of determining the general policy of the university both academic and non-academic, monitoring and control of the general university activities, and provide feedback improvements to the university, so the university has always in the path of vision and mission that has been determined.

The audit board is a functional unit that is implement the tasks and functions of the board of trustee to conduct an audit, both in academic and financial for the organization of the university. As a body established by the board of trustee, the tasks and functions of the audit board is comprehensive, they can perform independent audit of organs and work units throughout the university, and the results will be used to make improvements and corrections to the university, based on the principle of continuous improvement.

Meanwhile, the principal task of the university academic senate is to formulate academic policies and regulations that will be implemented by the university leaders and its staff. Every policy or academic processes are discussed and arranged by the university academic senate through plenary and commission meetings. The chairman and secretary of the university academic senate is a facilitator and catalyst for the realization of the detailed and transparent decisions. Hence, all policy will be submitted to the relevant internal organs.

The leader of university consists of the rector and vice rector. The key functions of the leader of university is implementing general policy of the board of trustee, academic policies of the university academic senate, and prepare a work plan and budget annually.

In preparing the academic program, the rector assisted by the directorate of planning and development that provide input to the integrated work program of the university, based on the university vision, mission, and goals universities. Hence, the work program will be implemented by the rector and its staffs. Thereby, there is a separation between planning and assignment as well as the implementation of the work plan by the rector with the rest of its work units. These mechanisms can be audited by the board of trustee through the audit board, and/or the results will be forwarded to the university academic senate as a feedback for further improvement.

The internal audit unit is the unit that will conduct regular audits on all unit under the Rectorate, monitoring the implementation of academic activities, budgets, rules and standard procedures, and control systems work in the university environment. Audit results from the internal audit unit will be used by the rector in policy making and subsequent decision, implement the Good Governance and as feedback to improve the mechanisms and procedures for the technical implementation of academic programs, financial and performance of every head of work units. The head of UAI appointed and responsible to the Rector, and the procedures, assignment, and position is regulated in the constitution and bylaws of the university.

The dean of faculty is one of the university organs and is under the Rector that facilitate, coordinate and lead the implementation of vocational education programs, academic, professional and continuing education, in a single or multi program, which are 
supported by the infrastructure of education. The dean of faculty also lead the implementation of academic and human resource development, both lecturers and staff, and responsible to the Rector. The structure of faculty may consist of one or more study program with academic coordinated implementation into a department, which plays a role in assisting the dean of faculty on the implementation of academic activities.

\section{THE LEADERSHIP IN HIGHER EDUCATION}

Based on the previous discussion above, leaders in a university become the spearhead that determines the success of an organization. Indeed, the participation of subordinates is also very important. However, it is the command of the leader that will guide the direction and objectives of the organization. In the Indonesia higher education environment, the role of the rector or director as a leader seems to be key in the success of a university (Tamin, 2015). Therefore, the variety of academic products generate by a university, for instance graduates, research, and innovation can provide value added to the development of the country and nation (Sumarni, 2010).

The leadership distinguish between managers and leaders. Managers usually focus on the process of planning, organize, direct, coordinate and control (Austin \& Jones, 2016). Meanwhile, leaders may include managers who focus on vision, align, coach \& trust, empowerment, and care. The managers are appointed, authority is given to carry out their functions and duties (Tamin, 2015).

In a university environment, leaders can be called as the academic leaders (Tamin, 2015). An academic leaders are: 1) Have the academic authority; 2) His authority is recognized because it is trusted by his partner; 3) Based on their high capacity and excellent track record; 4) His leadership is earned; 5) Academic leaders are given the mandate to lead, not asking to be elected; no campaign and branding required.

According to the Indonesian Government Regulation No. 60 of 1999 on Higher Education, the structural academic leader may consist of the Chairperson of the university academic senate and or the faculty academic senate. Moreover, a functional academic leader usually consists of lecturer, associate professor and professor. The leadership is achieved because of their achievements/competencies, their authority is recognized because they are trusted by their colleagues and given the mandate to lead. A university needs to apply academic leadership (functional) everywhere (Tamin, 2015). According to Tamin (2015), all lecturers, associate professor, and professors are leaders, especially for students. An academic leader must be trusted, become a role model, visionary; broad dimensions (natural, human and social) and high wisdom (Sadjad, 2004).

At the university level, the university's executive leadership (Rector and Dean) is a combination of the abilities of academic leaders and manager skill (Austin \& Jones, 2016). The university executive leaders must have a guarantee of competence (capacity to lead) and a good track record (Austin \& Jones, 2016). Since it is transparent, open and there are many candidates (from entire lecturers) in the nomination of the university's executive leadership, it is necessary to find and do the election through a selection committee (Tamin, 2015).

The election process is based on selection rather than election based on capacity as well as track record and does not require campaigning and imaging (Tamin, 2015). Moreover, it needs an acceptability that is an acknowledgment of competence and achievements (earned), instead of acceptability through ballots and can also be 
demonstrated through the support of the university academic senate and the faculty academic senate (Austin \& Jones, 2016; Tamin, 2015).

\section{THE ACTUALIZATION OF GOOD MANAGEMENT IN THE UNIVERSITY}

In order to elevates the good management at the higher education environment, there are a number of important points (Tamin, 2015) that must be considered, namely:

1. The implementation of a governance system that guarantees a mechanism of check and balance as well as shared governance and collegiality. In the perspective of checks and balances, the governance is a process of delegation of authority for decision making. The delegation process requires the checks and balances on the authorized party to make decisions. Intrinsically, it will be associated to the perspective of decision making, where the governance will be related to the effectiveness of decisions making.

2. Implement a transparent management system. Implement a system that aims to avoid conflicts of interest and dual positions, reduce the practice of corruption, collusion and nepotism. improve efficiency and effectiveness, and use the principles of meritocracy and transparency in the appointment/dismissal of structural officials and staff. This also includes implementing a system of accounting and financial management that can be audited. Then, there are academic annual reports, and annual financial reports that are audited by public accountant.

3. Management system which includes academic management systems and resource management systems. The management system should include the functional areas of the university, including academic management system (tri-dharma university) and resource management system that includes, human resource systems, financial systems, infrastructure, data and information systems.

4. The leadership of the university is obliged to comply with applicable regulations. University leaders is mandatory and subject the laws and regulations, and adhere to the strategic policy framework (e.g. the planning system of long-term, mediumterm/RENSTRA, and annual/RKAT) that has been established by the governing legal entity. Then apply the strategic planning system effectively and efficiently at the beginning of the academic year. University leaders define and fullfill the performance targets (based on the key performance indicators) that have been proposed and approved by the governing legal entity. The university leader should implement and execute quality standards mandated by the National Accreditation Board for Higher Education. University leaders are responsible for the submission of annual reports, which consist of audited annual financial reports and annual academic reports.

Moreover, the leadership of the university (the rector along with the deputy) and the university academic senate are important elements (Tamin, 2015). The academic senate has primary authority, not only academic, but also the direction and policy of higher education. The academic senate organization is also collective, and decision making is done together. The rector is the executive who is responsible for operational actions, protecting the interests of the university institutions and making execution decisions. In addition, the interaction on campus is based on academic interaction (scientific authority), not executive or bureaucratic authority (Sumarni, 2010). 
In general, the organization of a university is a matrix, so it is necessary to differentiate between the resource organization and program organizations (Tamin, 2015). The resource organizations refer to managing resources (lecturers, education staff, educational facilities). Generally have a normative body (e.g. the faculty has a faculty academic senate) and manage the program. Meanwhile, the program organizations refer to program implementation (study programs, research \& community service); transfer of resources, especially lecturers from program organizations (e.g. Research \& Community Service Institute). Thus, resource organizations and programs must be able to work together in all academic activities. In particular, resource organizations must adapt and accommodate various management needs. As well, it must be implemented in a transparent, accountable and efficient.

Therefore, Muhi (2011), Sumarni (2010) and Tamin (2015) suggest several important points that must be considered in order to improve good management in the university, among others, first, the university leaders need to be equipped with the function of monitoring and quality assurance. Secondly, the checks and balances of executive authority (rector and dean) are required, which can be carried out by the university academic senate and the faculty academic senate. Finally, the conflicts of interest must be avoided as well as dual positions. Thus, the implementation of good university governance is expected to improve the quality of the organization of higher institutions as a whole, so that the higher institutions can meet the expectations of the community in order to educate the nation's life.

\section{CONCLUSIONS AND RECOMMENDATIONS}

\section{Conclusions}

Good University Governance is basically setting the organizational structure, the process of business, as well as program and activities in the planning procedure. In order to achieve this, it is necessary to pay attention to principles such as transparency, accountability (to stakeholders), responsibility, independence (in decision making), fairness, quality assurance and relevance, effectiveness and efficiency.

Leaders are different from managers. The leader is chosen while the manager is appointed. Earned the academic leadership, authority is obtained because it is recognized by the colleague. Academic leaders are mandated to lead, not ask to be elected and no campaign or branding required. Rector is a combination of academic leaders and managers.

\section{Recommendations}

A university should apply academic leadership everywhere (become a role model for students). The appointment is more selection rather than election and its implementation through a selection committee. It is necessary to implement the checks and balances of executive authority, which can be performed by the university and faculty academic senate. Provide the function of monitoring and quality assurance in the organization. Avoid conflicts of interest as well as multiple positions. The points mentioned above need to be considered in designing governance and development as well as implementing good management in a university. 


\section{REFERENCES}

Austin, I., \& Jones, G., A. (2016). Governance of higher education Global perspectives, theories, and practices. New York: Taylor and Francis.

Badan Pemeriksa Keuangan Republik Indonesia. (2013). BPK Bahas Pengelolaan dan Pertanggungjawaban Keuangan PTN. Available at: https://www.bpk.go.id/news/bpk-bahas-pengelolaan-dan-pertanggungjawabankeuangan-ptn

Bradley, D., Noonan, P., Nugent, H., \& Scales, B. (2008). Review of Australian higher education: Final report. Available at: http://www.voced.edu.au/content/ngv32134

Davidovitch, N., \& Iram, Y. (2015). Models of higher education governance: A comparison of Israel and other countries. Global Journal of Educational Studies, $1(1), 16-44$.

Lokuwaduge, C. D. S., \& Armstrong, A. (2015). The impact of governance on the performance of the higher education sector in Australia. Educational Management Administration \& Leadership, 43(5), 811 - 827.

Dobbins, M., \& Knill, C. (2009). Higher education policies in Central and Eastern Europe: Convergence toward a common model? Governance, 22(3), 397-430. http://dx.doi.org/10.1111/j.1468-0491.2009.01445.x

Dobbins, M., Knill, C., \& Vögtle, E. M. (2011). An analytical framework for the crosscountry comparison of higher education governance. Higher Education, 62(5), 665683. http://dx.doi.org/10.1007/s10734-011-9412-4

Jalal, F., \& Supriadi, D. (2001). Reformasi pendidikan dalam konteks otonomi daerah. Jakarta : Depdiknas-Bapenas-Adicitakaryanusa.

Mizikaci, F. (2006). Higher education in Turkey. UNESCO-CEPES. Monographs on Higher Education. Available at: http://www.unesdoc.unesco.org/images/0014/001455/145584e.pdf

Muhi, A. H. (2010). Implementasi nilai-nilai good governance di perguruan tinggi. Bandung: Sekolah Pascasarjana Universitas Pendidikan Indonesia.

Muhi, A. H. (2011). Membangun good governance pada perguruan tinggi di indonesia. Thesis. Bandung: Universitas Pendidikan Indonesia.

Norton, A. (2012). Mapping Australian higher education. Carlton, Victoria, Australia: Grattan Institute. Available at: http://grattan.edu.au/wpcontent/uploads/2014/10/816-mapping-higher-education-2014.pdf

Panova, A. (2008). Governance structures and decision making in Russian higher education institutions. Problems of Economic Transition, 50(10), 65-82. http://dx.doi.org/10.2753/PET1061-1991501004

Peraturan Menteri Riset, Teknologi, dan Pendidikan Tinggi Republik Indonesia Nomor 16 Tahun 2018. Pedoman Tata Cara Penyusunan Statuta Perguruan Tinggi Swasta. Kementerian Riset, Teknologi, dan Pendidikan Tinggi Republik Indonesia. Jakarta

Peraturan Pemerintah No. 60 tahun 1999 Pendidikan Tinggi. Jakarta

Tamin, R. Z. (2015). Governance Perguruan Tinggi. Jakarta: Direktorat Kelembagaan dan Kerjasama Ditjen Pendidikan Tinggi.

Sadjad, R. S. (2004). Good university governance : Sebuah pemahaman awal mengenai pengertian dan bagaimana seharusnya implikasinya dalam penyelenggaraan perguruan tinggi. Makasar: Universitas Hasanuddin Makassar. 
Stevenson, M. (2004). University governance and autonomy problems in managing access, quality and accountability. Proceeding of ADB Conference on University Governance. Denpasar, Indonesia.

Sumarni, S. (2009). Good university governance dan implikasinya terhadap pengembangan program studi pendidikan agama islam Fakultas Tarbiyah - UIN Sunan Kalijaga Yogyakarta. Jurnal Pendidikan Agama Islam, VI(1), 175 - 194

Undang-Undang No. 12 Tahun 2012. Pendidikan Tinggi. Jakarta 